\title{
Angiolymphoid Hyperplasia with Eosinophilia Located on the Forehead: A Possible Association with Oral Contraceptive Use?
}

\author{
Nantia-Eleni Theofilou ${ }^{a}$ Paolo Scolozzi ${ }^{a}$ Tommaso Lombardi ${ }^{b}$ \\ aDivision of Oral and Maxillofacial Surgery, Department of Surgery, University of \\ Geneva and University Hospitals of Geneva, Geneva, Switzerland; \\ ${ }^{b}$ Oral Medicine and Oral Maxillo-Facial Pathology Unit, Division of Oral and Maxillofacial \\ Surgery, Department of Surgery, University of Geneva and University Hospitals of Geneva, \\ Geneva, Switzerland
}

\section{Keywords}

Angiolymphoid hyperplasia with eosinophilia $\cdot$ Skin $\cdot$ Pathogenesis $\cdot$ Contraceptive pill

\begin{abstract}
Angiolymphoid hyperplasia with eosinophilia (ALHE) is an uncommon benign vasoproliferative tumor characterized by nodules, papules or plaques localized principally in the head and neck region. Histopathological examination reveals hyperplastic blood vessels lined by large endothelial cells, accompanied by an infiltrate of inflammatory cells including eosinophils. The pathogenetic mechanism remains unclear, although different theories have been proposed. Various treatment strategies have been described, but surgery remains the treatment of choice. We describe the case of a young woman with ALHE taking an oral contraceptive pill suggesting a possible etiopathogenetic relationship.

\section{Introduction}

Angiolymphoid hyperplasia with eosinophilia (ALHE) is a benign tumor that is characterized by a vascular proliferation associated with infiltration from lymphocytes and eosinophils. It was first described in 1969 by Wells and Whimster and considered as a late stage of Kimura disease [1]. Nowadays, the two disorders are considered separate entities.

A systematic review of the literature conducted in 2016 by Adler et al. [1] confirmed 908 cases. From 2016 to 2019, an additional 60 cases have been reported in the literature. Young 
Fig. 1. Patient presenting at the emergency department with a subcutaneous nodule.

\begin{tabular}{l|l}
\hline DOI: $10.1159 / 000503743$ & $\begin{array}{l}\text { (c) } 2019 \text { The Author(s). Published by S. Karger AG, Basel } \\
\text { www.karger.com/dpa }\end{array}$ \\
\hline
\end{tabular}

Theofilou et al.: Hormones Possibly Implicated in the Etiopathogenesis of Angiolymphoid Hyperplasia with Eosinophilia

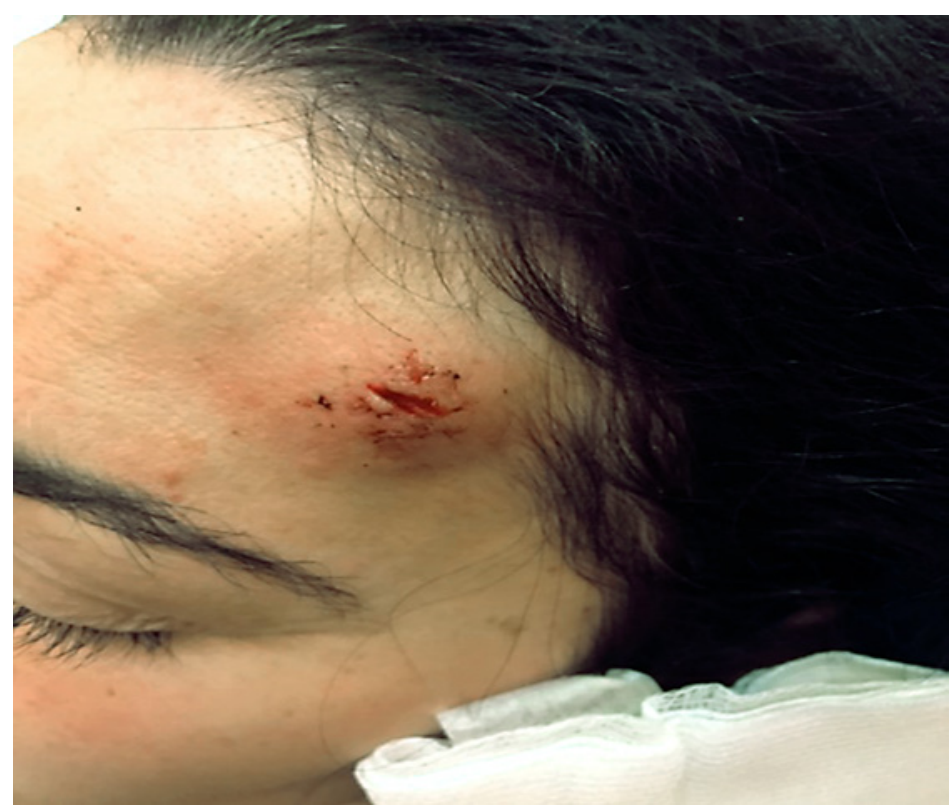

to middle-aged adults are usually affected, with a mean age of 37.6 years with no gender predilection [1]. Some authors report a higher incidence in women but Adler et al. found no statistically significant differences between genders. A possible explanation - that was suggested by Guo and Gavino [2] - is that in one of the biggest series of 116 patients by Olsen and Helwig [3], the population was predominantly masculine due to the selection of patients from a group of military and Veterans Health Administration hospitals leading therefore to a male sex bias [2].

The lesions are localized mainly on the head and neck, especially affecting the ear and preauricular area (36.3\%) [1]. Locations less frequently encountered are the oral mucosa, salivary glands, parapharyngeal space, breast, colon, lung and upper limbs and fingernails [1, 4-6].

They typically manifest as intradermal or subcutaneous single or multiple papules or nodules, or plaques. Symptoms reported include pruritus, pain, bleeding and pulsation [1].

Approximately $20 \%$ of patients have blood eosinophilia without elevation of immunoglobulin E (IgE) levels [3].

Histopathologically, ALHE is characterized by prominent vascular hyperplasia. The main pathognomonic characteristic is the presence of epithelioid endothelial cells lining the vascular wall and projecting inside the vascular lumen giving a "cobblestone" appearance. These cells have large nuclei and abundant eosinophilic cytoplasm. The second defining characteristic of ALHE is inflammation. Lymphocytes and eosinophils diffusely surround and may infiltrate the blood vessels [1].

Differential diagnosis must be made between ALHE and Kimura disease which were thought to be the same pathology in the past $[1,7]$.

The pathogenetic mechanisms of ALHE remain uncertain. Many hypotheses have been proposed [1, 3, 8-14].

Surgery is the main treatment, but various treatment strategies have been described in the literature with varying results (e.g., tacrolimus, propranolol, cryotherapy) [2].

We describe a case occurring in a patient taking oral contraceptive pills suggesting a possible association between hormones and ALHE. 
Fig. 2. Histopathology showing proliferation of vascular channels surrounded by a chronic, inflammatory infiltrate with eosinophils. The vessels are lined by plump endothelial cells. HE. $\times 20$.

Theofilou et al.: Hormones Possibly Implicated in the Etiopathogenesis of Angiolymphoid Hyperplasia with Eosinophilia

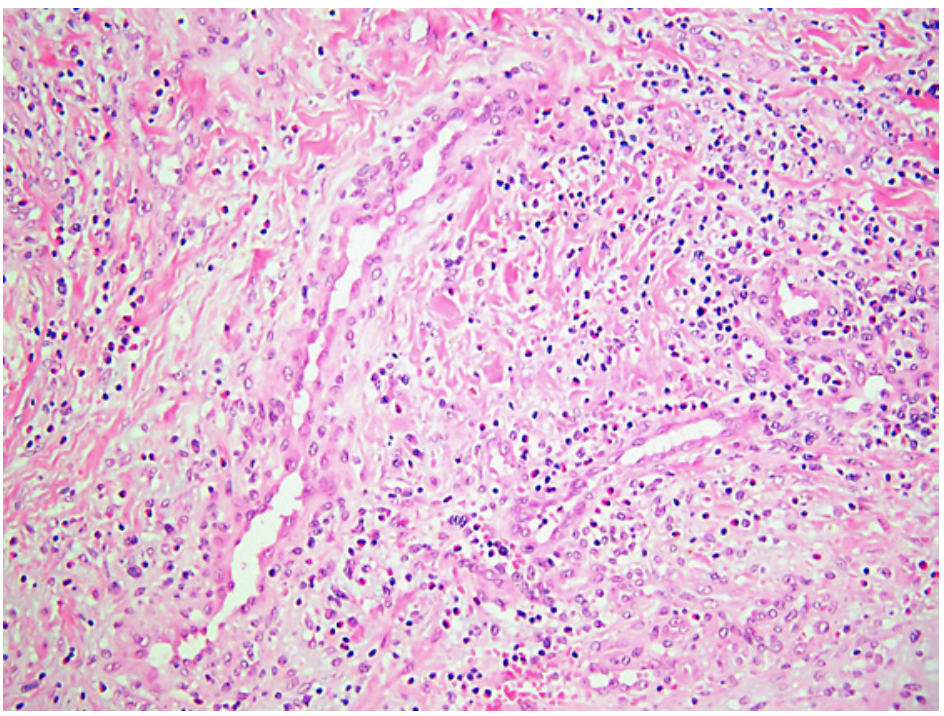

Fig. 3. Higher magnification showing proliferated vascular channels and infiltration by numerous eosinophils. HE. $\times 32$.

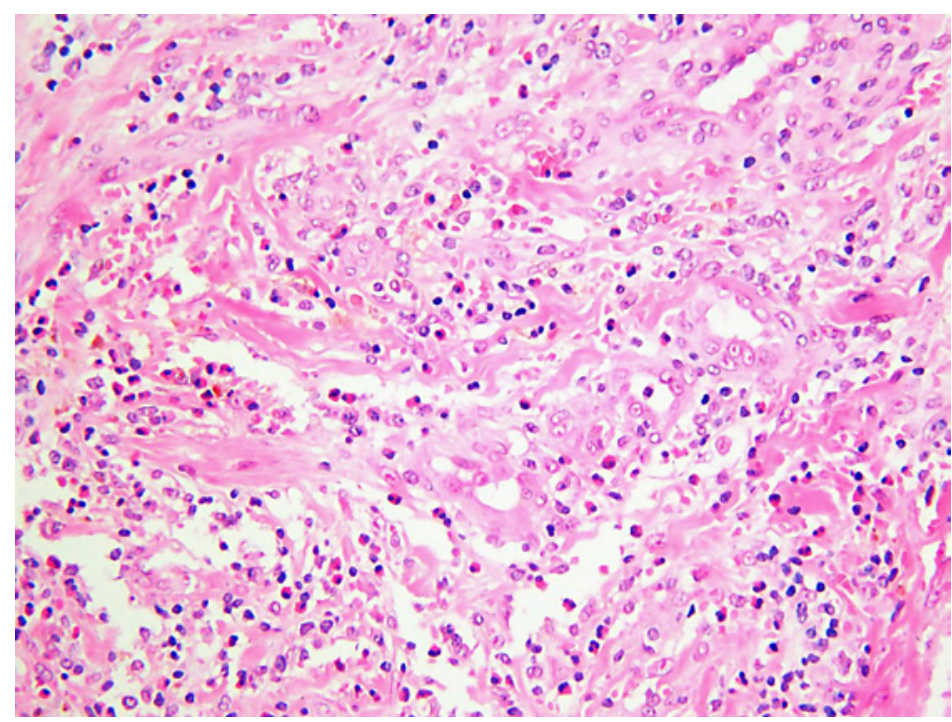

\section{Case Report}

A 34-year-old woman was transferred to the emergency department, University Hospitals of Geneva, after an unsuccessful attempt by her general practitioner to excise a subcutaneous nodule located on the forehead. The procedure was stopped due to excessive bleeding intraoperatively. Her medical history was uneventful. She had been taking contraceptive pills for 20 years. She reported that the nodule had been present for 5 months and that a nodule on the scalp had been successfully excised by her general practitioner several years before. We failed to retrieve information about whether histopathological examination was performed at that time or not. Upon clinical examination, a well-circumscribed, subcutaneous nodule was observed, with a diameter of about $2 \mathrm{~cm}$, located on the left side of the forehead, associated with an inflammatory reaction (Fig. 1). Surgical excision was performed under local anesthesia. An elliptical incision was performed respecting the Langer lines of minimal tension on the skin. The lesion was resected in totality, and the skin was closed using simple interrupted sutures. Histopathological examination revealed a florid lobular vascular CD31-positive proliferation, lined by 
Table 1. Cases of angiolymphoid hyperplasia with eosinophilia associated with pregnancy or contraception

\begin{tabular}{|c|c|c|c|c|c|c|c|}
\hline & Cases & $\begin{array}{l}\text { Age, } \\
\text { years }\end{array}$ & $\begin{array}{l}\text { Pregnancy/ } \\
\text { contraception }\end{array}$ & $\begin{array}{l}\text { Localization of } \\
\text { lesions }\end{array}$ & Lesions, $n$ & $\begin{array}{l}\text { Occurrence/aggravation/ } \\
\text { regression after } \\
\text { discontinuation }\end{array}$ & Treatment \\
\hline $\begin{array}{l}\text { Olsen and } \\
\text { Helwig [3], } \\
1985\end{array}$ & 5 & $\begin{array}{l}\text { Not } \\
\text { mentioned }\end{array}$ & Pregnancy & Not mentioned & $\begin{array}{l}\text { Single, } \\
\text { multiple }\end{array}$ & Occurrence, aggravation & Not mentioned \\
\hline $\begin{array}{l}\text { Moy et al. } \\
\text { [15], } 1992\end{array}$ & 2 & $\begin{array}{l}28 \\
28\end{array}$ & $\begin{array}{l}\text { Pregnancy, } \\
\text { contraception }\end{array}$ & Forehead, scalp & Multiple & $\begin{array}{l}\text { Occurrence, aggravation, } \\
\text { regression }\end{array}$ & $\begin{array}{l}\text { Electodessication } \\
\text { curettage, } \\
\text { laser/surgical } \\
\text { excision }\end{array}$ \\
\hline $\begin{array}{l}\text { Hollo et al. } \\
{[16], 2005}\end{array}$ & 1 & 28 & Pregnancy & $\begin{array}{l}\text { Eyebrow, } \\
\text { temporal region }\end{array}$ & 2 & Occurrence & Surgical excision \\
\hline $\begin{array}{l}\text { Zarrin- } \\
\text { Khameh et al. } \\
{[17], 2005}\end{array}$ & 1 & 33 & Pregnancy & Ear & 1 & Occurrence & Surgical excision \\
\hline $\begin{array}{l}\text { Ceyhan et al. } \\
{[18], 2011}\end{array}$ & 1 & 33 & Pregnancy & Ear & 1 & Occurrence & Surgical excision \\
\hline $\begin{array}{l}\text { Marcum et al. } \\
{[19], 2011}\end{array}$ & 1 & 29 & Pregnancy & Occipital scalp & Multiple & $\begin{array}{l}\text { Aggravation and } \\
\text { occurrence of new lesions }\end{array}$ & Laser \\
\hline $\begin{array}{l}\text { Parimalam } \\
\text { and Thomas } \\
{[21], 2016}\end{array}$ & 1 & 33 & $\begin{array}{l}\text { Pregnancy, } \\
\text { history of } \\
\text { contraception }\end{array}$ & Ear & Multiple & Occurrence & Surgical excision \\
\hline $\begin{array}{l}\text { Haritha et al. } \\
{[20], 2016}\end{array}$ & 3 & $\begin{array}{l}27 \\
25 \\
32\end{array}$ & Pregnancy & $\begin{array}{l}\text { Postauricular, } \\
\text { scalp }\end{array}$ & Multiple & $\begin{array}{l}\text { Occurrence, aggravation, } \\
\text { regression }\end{array}$ & $\begin{array}{l}\text { Surgical excision, } \\
\text { cryotherapy }\end{array}$ \\
\hline
\end{tabular}

hypertrophic endothelial cells, occasionally protruding inside the lumen (Fig. 2) and surrounded by inflammatory infiltrate of variable density containing lymphocytes, eosinophils and mast cells (Fig. 3). Rare lymphoid follicles were noted. A diagnosis of ALHE was established. Her serum eosinophilic count was normal. No recurrence was noted at the 12-month follow-up visit.

\section{Discussion}

Many hypotheses about the pathogenetic mechanisms of ALHE have been made. A reactive mechanism secondary to vascular damage has been suggested [3, 8]. Other authors have claimed that ALHE is of neoplastic origin and specifically that it is a T-cell lymphoproliferative disorder [9-11]. The role of the renin-angiotensin system in provoking vessel proliferation has equally been discussed [12]. Another hypothesis is that the disorder could be explained by an immunological pathogenetic mechanism [13]. A possible association with the HIV virus has also been reported in the literature [14], as well as human T-cell lymphotropic virus or human herpesvirus 8 [1]. An etiopathogenetic factor that has not been adequately studied is the impact of sex hormones, especially estrogen.

Olsen and Helwig [3] observed a development of lesions in 4 patients and also an increase in nodular size of preexisting nodules in 1 patient during pregnancy and thus were the first to suggest an association with hyperestrogen states in the pathogenesis of ALHE. Since then, other cases of occurrence or recurrence or aggravation of ALHE during pregnancy have been reported in the literature [15-20]. By contrast, to the best of our knowledge, only 2 cases of ALHE occurring in patients with a history of contraceptive pill use have been described [15, 
Theofilou et al.: Hormones Possibly Implicated in the Etiopathogenesis of

Angiolymphoid Hyperplasia with Eosinophilia

$20,21]$. Resolution of lesions after discontinuation of contraceptive pills and decrease in size after pregnancy have also been described $[15,20]$.

All reported cases of ALHE associated with hormones are presented in Table 1.

The occurrence and aggravation of the disease during pregnancy as well as the regression of the lesions after discontinuation of the hormonal effect could lead to the hypothesis that hormones play a role in the pathogenesis of ALHE, but the mechanism remains undetermined.

The hormonally responsive behavior of many other vascular tumors has been studied. An etiopathogenetic link between pyogenic granuloma and pregnancy is widely accepted [22, 23]. The impact of hormones on the development of hemangiomas has also been studied by various authors [24-27].

The pathogenetic pathways by which hormones lead to vascular tumors have been well established. More precisely, estrogen enhances endothelial changes that lead to angiogenesis [28]. The stimulation of growth factors such as basic fibroblast growth factor, insulin-like growth factor, transforming growth factor- $\beta$, vascular endothelial growth factor, matrix metalloproteinase-9, endothelial progenitor cells and nitric oxide by estrogen $[29,30]$ is a crucial mechanism that results in proliferation of vascular endothelial cells leading to the development of lesions such as ALHE. Further studies need to be conducted to prove that hypothesis.

As far as differential diagnosis is concerned, ALHE should be distinguished from Kimura disease, which is typically characterized by a large subcutaneous mass localized in the periauricular or submandibular region. Young Asian males are most commonly affected. It is a systemic immunological process characterized by lymphadenopathy, eosinophilia and increased serum levels of IgE. Renal disease and asthma are commonly present [7]. Histologically, florid lymphoid follicles and eosinophilic infiltrates are typical histological findings of Kimura disease [7].

Many therapeutic options have been used for ALHE including radiotherapy, laser therapy, photodynamic therapy, cryotherapy, electrodessication and medications such as corticosteroids, pentoxifylline, interferon- $\alpha$, imiquimod, tacrolimus, thalidomide, oral isotretinoin, acitretin and intralesional chemotherapeutic agents [31]. However, surgical excision remains the gold standard treatment [2]. A recurrence rate of $30 \%$ has been reported in the literature in cases of incomplete excision [32].

\section{Statement of Ethics}

The patient has given written informed consent to publish the case (including publication of images).

\section{Disclosure Statement}

The authors have no conflicts of interest to declare.

\section{Funding Sources}

No funding sources or sponsors to declare.

\section{References}

1 Adler BL, Krausz AE, Minuti A, Silverberg JI, Lev-Tov H. Epidemiology and treatment of angiolymphoid hyperplasia with eosinophilia (ALHE): A systematic review. J Am Acad Dermatol. 2016 Mar;74(3):506-12.e11.

2 Guo R, Gavino AC. Angiolymphoid hyperplasia with eosinophilia. Arch Pathol Lab Med. 2015 May; 139(5): 683-6. 
3 Olsen TG, Helwig EB. Angiolymphoid hyperplasia with eosinophilia. A clinicopathologic study of 116 patients. J Am Acad Dermatol. 1985 May;12(5 Pt 1):781-96.

4 Chung SR, Tan JS, Selvarajan S. Intravascular angiolymphoid hyperplasia with eosinophilia (ALHE) of the hand. J Hand Surg Eur Vol. 2015 Sep;40(7):750-1.

5 Di Vitantonio H, De Paulis D, Ricci A, Raysi SD, Marzi S, Del Maestro M, et al. Angiolymphoid hyperplasia with eosinophilia and entrapment of the ulnar nerve. Surg Neurol Int. 2016 Mar;7(6 Suppl 5):S160-3.

6 Halteh P, Magro C, Lipner SR. Angiolymphoid hyperplasia with eosinophilia of the nail unit. Dermatol Online J. 2017 Jun;23(6):23-6.

7 Totti de Bastos J, Roos Mariano da Rocha C, Chaves e Silva P, Pires de Freitas B, Freire Cassia F, Regazzi Avelleira JC. Angiolymphoid hyperplasia with eosinophilia versus Kimura's disease: a case report and a clinical and histopathological comparison. J An Bras Dermatol. 2017;92(3):392-4.

8 Fetsch JF, Weiss SW. Observations concerning the pathogenesis of epithelioid hemangioma (angiolymphoid hyperplasia). Mod Pathol. 1991 Jul;4(4):449-55.

9 Andreae J, Galle C, Magdorf K, Staab D, Meyer L, Goldman M, et al. Severe atherosclerosis of the aorta and development of peripheral T-cell lymphoma in an adolescent with angiolymphoid hyperplasia with eosinophilia. Br J Dermatol. 2005 May;152(5):1033-8.

10 Gonzalez-Cuyar LF, Tavora F, Zhao XF, Wang G, Auerbach A, Aguilera N, et al. Angiolymphoid hyperplasia with eosinophilia developing in a patient with history of peripheral T-cell lymphoma: evidence for multicentric T-cell lymphoproliferative process. Diagn Pathol. 2008 May;3(1):22.

11 Kempf W, Haeffner AC, Zepter K, Sander CA, Flaig MJ, Mueller B, et al. Angiolymphoid hyperplasia with eosinophilia: evidence for a T-cell lymphoproliferative origin. Hum Pathol. 2002 Oct;33(10):1023-9.

12 Fernandez LA, Olsen TG, Barwick KW, Sanders M, Kaliszewski C, Inagami T. Renin in angiolymphoid hyperplasia with eosinophilia. Its possible effect on vascular proliferation. Arch Pathol Lab Med. 1986 Dec;110(12):1131-5.

13 Grimwood R, Swinehart JM, Aeling JL. Angiolymphoid hyperplasia with eosinophilia. Arch Dermatol. 1979 Feb;115(2):205-7.

14 D’Offizi G, Ferrara R, Donati P, Bellomo P, Paganelli R. Angiolymphoid hyperplasia with eosinophils in HIV infection. AIDS. 1995 Jul;9(7):813-4.

15 Moy RL, Luftman DB, Nguyen QH, Amenta JS. Estrogen receptors and the response to sex hormones in angiolymphoid hyperplasia with eosinophilia. Arch Dermatol. 1992 Jun;128(6):825-8.

16 Hollo P, Marschalko M, Sikos G, Harsing J, Horvath A. Angiolymphoid hyperplasia with eosinophilia in pregnancy. J Eur Acad Dermatol Venereol. 2005 Sep;19(5):645-6.

17 Zarrin-Khameh N, Spoden JE, Tran RM; Zarrin- Khamesh N. Angiolymphoid hyperplasia with eosinophilia associated with pregnancy: a case report and review of the literature. Arch Pathol Lab Med. 2005 Sep;129(9): 1168-71.

18 Ceyhan AM, Akkaya VB, Yildirium M, Karahan N. A case of angiolymphoid hyperplasia with eosinophilia aggravated during pregnancy. Balkan Med J. 2011;28:319-21.

19 Marcum CB, Zager JS, Bélongie IP, Messina JL, Fenske NA. Profound proliferating angiolymphoid hyperplasia with eosinophilia of pregnancy mimicking angiosarcoma. Cutis. 2011 Sep;88(3):122-8.

20 Haritha K, Satya S, Raghurama Rao G, Durga Prasad BK, Prasad Chowdary A. Angiolymphoid hyperplasia with eosinophilia during pregnancy: a study of three cases with a brief review of literature. J NTR Univ Health Sci. 2016;5(4):295-8.

21 Parimalam K, Thomas J. Angiolymphoid hyperplasia with eosinophilia associated with pregnancy: a rare report. Indian J Dermatol. 2016 Jan-Feb;61(1):125.

22 Kamal R, Dahiya P, Puri A. Oral pyogenic granuloma: various concepts of etiopathogenesis. J Oral Maxillofac Pathol. 2012 Jan;16(1):79-82.

23 Yuan K, Wing LY, Lin MT. Pathogenetic roles of angiogenic factors in pyogenic granulomas in pregnancy are modulated by female sex hormones. J Periodontol. 2002;73(7):701-8.

24 Conter RL, Longmire WP Jr. Recurrent hepatic hemangiomas. Possible association with estrogen therapy. Ann Surg. 1988 Feb;207(2):115-9.

25 Ma'ayeh M, Purandare N, Harrison M, Geary MP. A rapidly enlarging cutaneous hemangioma in pregnancy. Clin Pract. 2014 Oct;4(2):644.

26 Glinkova V, Shevah O, Boaz M, Levine A, Shirin H. Hepatic haemangiomas: possible association with female sex hormones. Gut. 2004 Sep;53(9):1352-5.

27 Nichols GE, Gaffey MJ, Mills SE, Weiss LM. Lobular capillary hemangioma. An immunohistochemical study including steroid hormone receptor status. Am J Clin Pathol. 1992 Jun;97(6):770-5.

28 Schnaper HW, McGowan KA, Kim-Schulze S, Cid MC. Oestrogen and endothelial cell angiogenic activity. Clin Exp Pharmacol Physiol. 1996 Mar;23(3):247-50.

29 Sun ZY, Yang L, Yi CG, Zhao H, Han DL, Yang T, et al. Possibilities and potential roles of estrogen in the pathogenesis of proliferation hemangiomas formation. Med Hypotheses. 2008 Aug;71(2):286-92.

30 Xiao X, Liu J, Sheng M. Synergistic effect of estrogen and VEGF on the proliferation of hemangioma vascular endothelial cells. J Pediatr Surg. 2004 Jul;39(7):1107-10.

31 Pankaj Kumar D, Swagata. Angiolymphoid hyperplasia with eosinophilia, a case report. Int J Otol Head Neck Surg. 2012;1:44-7.

32 Ramchandani PL, Sabesan T, Hussein K. Angiolymphoid hyperplasia with eosinophilia masquerading as Kimura disease. Br J Oral Maxillofac Surg. 2005 Jun;43(3):249-52. 